\title{
Vulnerability of the agricultural sector of Latin America to climate change
}

\author{
Walter E. Baethgen* \\ International Fertilizer Development Centre (Latin America), Javier Barrios Amorín 870, Piso 3, Montevideo, Uruguay
}

\begin{abstract}
The vulnerability of the agricultural sector in any region to future possible climate-change scenarios is determined to a great extent by the vulnerability of the sector to current climatic, economic and policy scenarios. Agricultural systems which are currently subject to extreme climatic interannual variability (drought, flood, storms, etc.) are likely to become even more vulnerable under the most commonly expected scenarios of climate change (i.e. increased temperatures, increased rainfall variability). Similarly, agricultural systems which are currently subject to drastic changes in economic and policy scenarios are also prone to become more vulnerable under expected climate-change conditions. The agricultural sector of Latin America has been subject to important variations in economical conditions and policies. These conditions have affected the structure of agricultural production, and resulted in a large reduction of the number of small farmers, who have migrated to poor metropolitan areas. Even for larger, commercial farmers, unstable and often inconsistent agricultural policies have increased the vulnerability of the sector. Additionally, large areas of Latin America are already affected by current interannual climatic variability related to the length of rainy seasons and the occurrence of extreme events (droughts, floods, etc.). The few studies conducted in the region to specifically assess the impact of climate change on agriculture have revealed expected reductions and increased variability in crop productivity. Similar results should be expected in the vast regions devoted to livestock production, since the systems are based on a fragile balance of nutrients, available water, stocking rates and pasture species. The characteristics of the current situation described in this article demonstrate the vulnerability of Latin American agriculture to climate change. Preparing the agricultural sector to mitigate the potential negative effects of climate change will require strong and consistent efforts in both the scientific and policy sectors of the region.
\end{abstract}

KEY WORDS: Climate change - Latin America $\cdot$ Agriculture $\cdot$ Vulnerability $\cdot$ Policy $\cdot$ Economics

\section{INTRODUCTION}

The vulnerability of the agricultural sector in any region of the world to future possible climate change scenarios is determined to a great extent by the vulnerability of the sector to current climatic, economic and policy scenarios. Agricultural systems which are currently subject to extreme climatic interannual variability (drought, flood, storms, etc.) are likely to become even more vulnerable under the most commonly expected scenarios of climate change (i.e. increased temperatures, increased rainfall variability).

\footnotetext{
•E-mail: baethgen@undp.org.uy
}

Similarly, agricultural systems which are currently subject to drastic changes in economic and policy scenarios (large changes in input/output price ratios, changes in subsidy-related policies, modifications in rural credit policies, etc.) are also prone to become more vulnerable under any situation which could result in higher yield variability and/or require increased investment, such as expected conditions under climate change.

Consequently, studies of agricultural systems' vulnerability to climate change must be conducted in the context of current vulnerability to these different scenarios. The objective of this article is to describe the main agricultural systems of Latin America and discuss the evolution of some of the most important 
national and regional agricultural policies in the last few decades. This description is necessary to define current vulnerability of the agricultural sector. A subsequent section of the article presents the results of the few studies that have been conducted specifically to determine the impacts of possible climate change scenarios on the agricultural sector in Latin America.

\section{GENERAL DESCRIPTION OF THE AGRICULTURAL SYSTEMS}

The participation of agriculture in the gross domestic product (GDP) of Latin American countries in the last 40 yr has been secondary. Although its importance varies throughout the region, the contribution of agricultural GDP to total GDP has been 10 to $12 \%$ in the last 20 yr. However, agriculture is still a key sector for the Latin American economy, since it employs a significant proportion (30 to $40 \%$ ) of the economically active population. Also, agriculture has been the largest foreign exchange earner of those countries where oil and minerals are not produced. Finally in the smaller, poorer countries of Latin America, agriculture is the most important employer, producer and export sector of the economy.

Latin American agricultural production systems are based on grain (maize, wheat, rice, soybeans, etc.) and livestock products (beef, wool, and dairy). The majority of the grain produced in the last 30 to 40 yr has come from medium to large commercial farms. Maize is the only grain crop which is still also being produced on small farms as a subsistence crop. The rest of the grains are grown on farms where the use of factors of production (land, labor and capital) has increased, especially in the period 1950 to 1980.

For example, while agricultural production during that period increased by $2.8 \% \mathrm{yr}^{-1}$, the agricultural population remained basically constant (mainly due to migration to metropolitan areas). Thus, agricultural labor productivity more than doubled in that period. The number of tractors increased by more than 4 times, which in turn allowed for the expansion of the cultivated area. These decades were also characterized by a very large increase in the use of fertilizers and pesticides. This intensification in the use of capital was not extended to irrigation, which is still roughly $10 \%$ of the total cropped area. The region's abundance of land and the high cost of irrigation result in advantages for cultivating new rainfed lands compared to introducing irrigation.

The other main agricultural product in Latin America is livestock. The animal production system of the region, especially in South America, is probably unique in the world: most of the livestock production is based on permanent pastures. The majority of the area devoted to beef and wool production is covered with native species, and only 10 to $30 \%$ of the area is improved with the establishment of more productive species and/or with fertilizer application. One of the main subregions for beef and wool production in South America is the Pampas, covering a vast area in Argentina, most of Uruguay and southern Brazil. Here the systems take advantage of the relatively highfertility soils and productive temperate or subtropical pasture species.

The other principal subregion for animal production is located in the South American Savannas and includes the Brazilian Cerrados and the Venezuelan and Colombian Llanos (total area of approximately 200 million ha). Production systems in this subregion are based on low-fertility, acidic soils with very lowquality native pastures. During the last 10 to $15 \mathrm{yr}$ farmers have started establishing African pastures (e.g. Brachiaria). Such improved pastures, which are estimated to currently cover 50 million ha in the Cerrados, are initially much more productive than the native species. However, after 5 to $10 \mathrm{yr}$ they usually suffer serious processes of degradation, with a consequent decreased productivity. In both the Pampas and the Cerrados, most of the livestock production comes from large or very large farms. Most dairy production systems in Latin America are much more intensive than beef and wool production. They are usually located around large urban centers, and typical production systems are based on the use of silage, hay, grain and improved pastures.

Latin American agricultural production is quite concentrated in a few countries. The values presented in Table 1 indicate that 3 countries (Brazil, Mexico and Argentina) are responsible for 70 to $90 \%$ of the total agricultural production of the region. This table also indicates that the area devoted to pasture production is 4 to 8 times larger that the one corresponding to crops, demonstrating the importance of livestock production in Latin America. A large proportion of the region's area is covered by the production systems described above, with the majority of the products coming from medium to large farms. However, typical production systems of most Andean countries in South America and all countries in Central America are based on small farms, with a large proportion of subsistence crops. These differences between subregions are reflected by the differences in their rural population. While only 10 to $30 \%$ of the total population in the non-Andean countries of South America live in rural areas, the corresponding figure for Central America and the Andean countries in South America is 40 to $60 \%$. 
Table 1. Major crop and pasture (livestock) areas in Latin America, and in Argentina, Brazil and Mexico. Values shown are in thousands of ha

\begin{tabular}{|c|c|c|c|c|c|c|}
\hline & $\begin{array}{c}\text { Latin } \\
\text { America }\end{array}$ & Argentina & Brazil & Mexico & $\begin{array}{l}\text { Sum for the } \\
3 \text { countries }\end{array}$ & $\%$ of total \\
\hline Rice & 6261 & 86 & 4143 & 88 & 4317 & 69 \\
\hline Maize & 25955 & 1959 & 11892 & 7151 & 21002 & 81 \\
\hline Wheat & 8575 & 4300 & 2162 & 985 & 7447 & 87 \\
\hline Sorghum & 3264 & 676 & 181 & 1380 & 2237 & 69 \\
\hline Soybeans & 15879 & 4865 & 9519 & 345 & 14729 & 93 \\
\hline Sunflower & 2486 & 2300 & 60 & 12 & 2372 & 95 \\
\hline Cotton & 3729 & 590 & 1769 & 252 & 2611 & 70 \\
\hline Beans & 8960 & 195 & 5508 & 2041 & 7744 & 86 \\
\hline Sugar cane & 8226 & 630 & 4202 & 540 & 5372 & 65 \\
\hline Coffee & 6351 & 0 & 2742 & 664 & 3406 & 54 \\
\hline Manioc & 2779 & 15 & 1959 & 0 & 1974 & 71 \\
\hline Sum of crops shown & 92465 & 15616 & 44137 & 13458 & 73211 & 79 \\
\hline Total crops & 102739 & 17160 & 49592 & 14789 & 81542 & 79 \\
\hline Arable & 131048 & 25000 & 50400 & 23150 & 98550 & 75 \\
\hline Irrigated & 15737 & 1680 & 2700 & 5180 & 9560 & 61 \\
\hline Pastures & 586921 & 142200 & 184200 & 74499 & 400899 & 68 \\
\hline Pasture/crop ratio & 5.71 & 8.29 & 3.71 & 5.04 & 4.92 & \\
\hline
\end{tabular}

\section{MAJOR POLICY CONCERNS}

During the period 1950 to 1980, Latin American governments were mainly oriented to the urban and industrial sectors of the economy. Policies were thus oriented to minimizing imports by protecting domestic industry with high tariff barriers. On the other hand, due to high inflation rates, real exchange rates appreciated, reducing the value of agricultural exports. As a result farmers received low prices for their products. For example, the World Bank (1986) estimated that in the 1970s Argentinean wheat and maize growers were receiving less than $60 \%$ of the world market price. Coffee growers in Brazil and Colombia received less than $50 \%$ of the world market price.

Trying to compensate for this discouraging scenario, governments oriented their policies to stimulating agricultural intensification, i.e. encouraging the adoption of high-yield technology and increasing capital use (Wiggins 1991). Governments started national crop programs and invested in roads, storage facilities, research and extension programs, etc. In addition, important subsidies on farm inputs, agricultural machinery, credit and marketing systems were also provided.

National crop programs with low-interest-rate loans (usually negative in real terms on account of inflation) were very common in these decades. These credit programs and many of the subsidy programs obtained much of their resources from the then easily available international loans. However, these policies presented several disadvantages: (1) they tended to favor only the larger commercial farmers, which worsened the already inadequate land distribution, (2) a large part of the cheap funds for agricultural development was diverted to other uses, (3) the subsidy programs resulted in dramatic increases in foreign debt, (4) the mechanization incentives resulted in lower demand for agricultural labor, increasing rural poverty and stimulating rural migration to metropolitan areas.

During the late 1980 s and 1990s most government policies reverted to: (1) the establishment of free trade agreements (global or regional), (2) incentives for the production of agricultural export goods, and (3) elimination of most or all the subsidized programs for agricultural production. This same period was characterized by low world market prices for cereals and livestock products. The new scenario implied conditions which were even more difficult for small farmers.

The 1980s were therefore characterized by an overall social and economic regression for the region: (1) GDP per capita decreased by more than $10 \%$ in the decade, (2) inflation rates became high or very high, and (3) foreign debt became uncontrollably high, with regional debt interest equivalent to $40 \%$ of the exports. These conditions resulted in a clear decrease in agricultural growth and in an increase of rural poverty. For example, a FAO study conducted in 1990 indicated that more than 90 million people in Latin America were living in poverty (FAO 1992). In 1993 the United Nations Economic Commission for Latin America and the Caribbean (CEPAL 1993) estimated that 
$53 \%$ of the rural households in the region had incomes which were less than the cost of a basic basket of food. CEPAL estimations for the growth of food production in Latin America for 1990 and 1991 was $0.8 \%$, about half of the corresponding figure for population growth.

\section{CURRENT POLICIES AND PRIORITIES OF GOVERNMENT ACTIONS}

The main driving force behind current agricultural policies in the region is the stimulation of export goods production. This major force is consistent with the recent numerous regional and global free trade agreements. It is also occurring at a time when most countries in the region are liberalizing markets, eliminating subsidies and low cost credit programs for agricultural production. These conditions are resulting in a continuous decrease in the number of small farmers who end up migrating to large metropolitan areas, with the known negative social consequences.

A second apparent driving force for many agricultural policies is the achievement of sustainable production systems. As a result, most government research and extension programs are oriented to eliminating, for example, problems associated with land degradation. In practice, however, very little is done in this respect when conflicting pressures or problems exist. For example, several national programs are stimulating agricultural production in new frontier lands (e.g. the Brazilian Cerrados), where adequate sustainable production systems have yet to be developed and adequately tested.

A typical area where government action has been limited to merely studying the problem is the contamination of agricultural land by the use of agri-chemicals (insecticides, fungicides, herbicides). Some evidence indicates that the resulting problems can be substantial, especially where intensive horticultural and fruit crop production is practiced, but no policy actions have yet been taken in this respect.

\section{VULNERABILITY TO CLIMATE VARIABILITY AND POSSIBLE ADAPTIVE STRATEGIES}

Scientific theory and most General Circulation Models (GCMs) suggest that the enhanced greenhouse effect caused by the increased atmospheric concentration of $\mathrm{CO}_{2}$ and other trace gases could lead to higher global surface temperatures and altered hydrological cycles (Hansen et al. 1983, 1988, Manabe \& Wetherald 1987, Wilson \& Mitchell 1987, Parry et al. 1988, IPCC 1990). Most possible climate change scenarios include higher atmospheric $\mathrm{CO}_{2}$ concentrations, higher temperatures, and changes in precipitation (increasing in some regions and decreasing in others). In Latin America, an increase in temperature would lead to shorter growing seasons, lower biomass production and lower grain yields. On the other hand, an atmosphere with higher $\mathrm{CO}_{2}$ concentration would result in higher photosynthesis rates and more efficient water use by crops (Acock \& Allen 1985, Cure 1985). Finally, precipitation increases would benefit areas with dry climates and would aggravate problems in regions with excess water, while a reduction in rainfall would have opposite effects. The impacts of climate change on crop yields will be the result of a balance between these negative and positive effects on plant growth and development (Fig. 1).

Fig. 2 shows the results of GISS model (Hansen et al. 1988) runs for several locations in Latin America. In general, GCM predictions for the region include temperature increases of 3.0 to $4.5^{\circ} \mathrm{C}$, and changes in rainfall of -10 to $+30 \%$. A change in the climatic conditions may significantly affect crop and pasture production. The impacts will probably vary across the region considering the existing variability in current climatic conditions. Few studies have been conducted to assess the impact of climate change on Latin American agriculture. During 1989 to 1992 the US EPA established a project in which crop simulation models (IBSNAT 1989) and GCMs were used to study the implications of climate change for international agriculture (Rosen- 


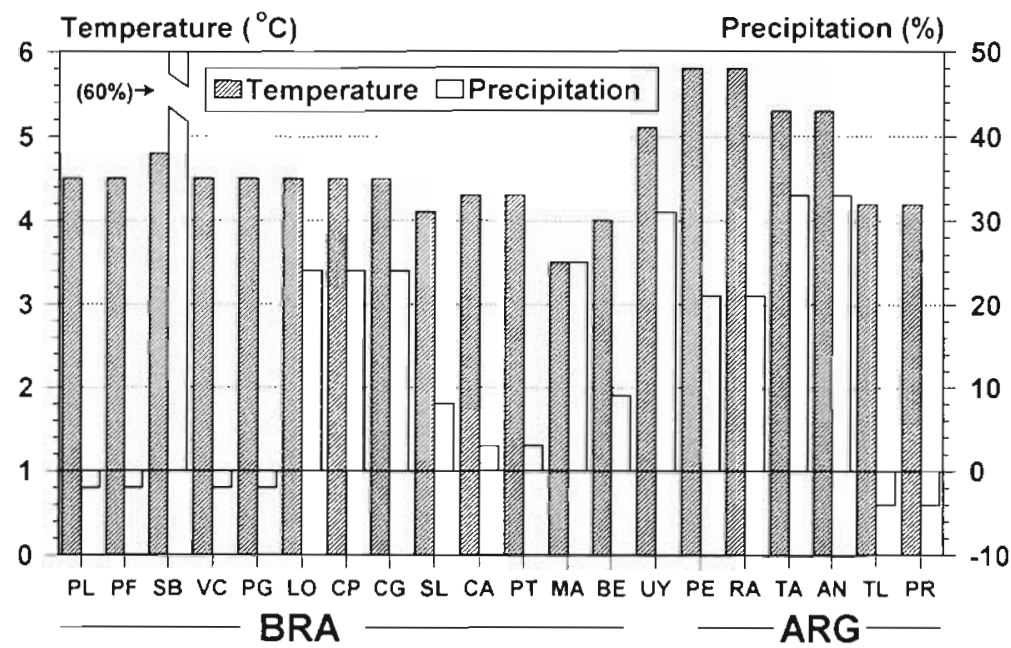

Fig. 2. Temperature and precipitation changes for several sites in Brazil (BRA), Uruguay (UY), and Argentina (ARG) as predicted by the GISS GCM ture seasonality, and where sufficient rainfall occurs at such earlier dates. For example, moving the planting dates in low-latitude regions would have a small effect due to the small variation in temperature throughout the year. On the other hand, moving planting dates in areas where temperature follows a clear seasonality (such as western Argentina) would be limited by water availability due to low rainfall. Other adaptive strategies in this first stage would also include improved plant nutrient management, better crop-pasture rotation systems, etc.

A second stage in adaptive strategies would involve establishing plant breeding programs especially oriented to producing cultivars adapted to high temperatures and/or resistant to drought. These breeding programs will probably be zweig \& Iglesias 1994). The results from 4 Latin American countries included in the project, and the results from a similar study conducted on a transect throughout the Pampas (Baethgen \& Magrin 1995), are summarized in Table 2.

Increased temperatures and shorter growing seasons would require serious adaptive strategies for the existing crop production systems. Three major stages would probably be needed to adapt to these conditions. The simplest adaptive strategies would involve moving planting to earlier dates in order to ensure that the grain filling stages will be carried out during periods of adequate temperatures. However, this strategy would only be meaningful in areas with clear temperadeveloped under crop disease pressures which will be higher than they currently are if there is an increase in temperature.

The third and most costly stage in adaptation strategies would typically involve the development of irrigation infrastructure. This strategy would be especially effective where rainy seasons would become shorter or more variable. However, as mentioned earlier, irrigation costs for the region have been considerably high and significant efforts would be needed from the governments.

The largest area which is clearly vulnerable to climate variability is the Brazilian Northeast. Like most agricultural areas of Latin America, this region has a

Table 2. Summary of impact studies of climate change on agriculture in Latin America. GISS: GCM of the Goddard Institute for Space Studies (NASA); UKMO: GCM of the United Kingdom Meteorological Office

\begin{tabular}{|c|c|c|c|c|c|}
\hline Study & $\begin{array}{l}\text { Climate } \\
\text { scenario }\end{array}$ & $\begin{array}{l}\text { Crop } \\
\text { scope }\end{array}$ & $\begin{array}{l}\text { Geographic } \\
\text { scope }\end{array}$ & $\begin{array}{l}\text { Yield } \\
\text { impact }\end{array}$ & $\begin{array}{l}\text { Other } \\
\text { impacts }\end{array}$ \\
\hline $\begin{array}{l}\text { Baethgen } \\
\text { (1994) }\end{array}$ & $\begin{array}{c}\text { GISS }\left(2 \times \mathrm{CO}_{2}\right) \\
+4.1^{\circ} \mathrm{C}\end{array}$ & $\begin{array}{l}\text { Wheat } \\
\text { Barley }\end{array}$ & Uruguay & $-30 \%$ & $\begin{array}{l}\text { Increased variability, higher } \\
\mathrm{N} \text { fertilizer requirement }\end{array}$ \\
\hline $\begin{array}{l}\text { Baethgen \& } \\
\text { Magrin (1995) }\end{array}$ & $\begin{aligned} \mathrm{UKMO} & \left(2 \times \mathrm{CO}_{2}\right) \\
+ & 5.4^{\circ} \mathrm{C}\end{aligned}$ & Wheat & $\begin{array}{l}\text { Argentina and } \\
\text { Uruguay }\end{array}$ & -5 to $-10 \%$ & $\begin{array}{l}\text { High response to } \mathrm{CO}_{2} \text {, high } \\
\text { response to precipitation }\end{array}$ \\
\hline $\begin{array}{l}\text { Siqueira et al. } \\
\text { (1994) }\end{array}$ & $\begin{array}{l}\text { GISS }\left(2 \times \mathrm{CO}_{2}\right) \\
+3.5 \text { to } 4.5^{\circ} \mathrm{C}\end{array}$ & $\begin{array}{l}\text { Wheat } \\
\text { Maize } \\
\text { Soybeans }\end{array}$ & Brazil & $\begin{array}{c}\text { Wheat: }-29 \% \\
\text { Maize: }-15 \% \\
\text { Soybeans: }+31 \%\end{array}$ & $\begin{array}{l}\text { Very high estimated } \\
\text { response to } \mathrm{CO}_{2} \text { in } \\
\text { soybeans }\end{array}$ \\
\hline $\begin{array}{l}\text { Liverman et al. } \\
\text { (1994) }\end{array}$ & $\begin{array}{l}\text { GISS }\left(2 \times \mathrm{CO}_{2}\right) \\
+4.1^{\circ} \mathrm{C}\end{array}$ & Maize & Mexico & $-16 \%$ & \\
\hline $\begin{array}{l}\text { Sala \& Paruelo } \\
(1994)\end{array}$ & $\begin{array}{l}\text { GISS }\left(2 \times \mathrm{CO}_{2}\right) \\
+4.8^{\circ} \mathrm{C}\end{array}$ & Maize & Argentina & $-17 \%$ & \\
\hline
\end{tabular}


rainy season during which crops are grown and a dry season with practically no rain. In the case of the Brazilian Northeast the rainy season is relatively short ( 3 to $4 \mathrm{mo}$ ) and the occurrence of years with no rainy season is frequent. These years are characterized by the occurrence of famine and large-scale human migration to metropolitan areas. Climatic conditions which result in shorter rainy seasons and/or increased frequency of rainless years would have extremely negative consequences.

A certain degree of vulnerability to climatic variability exists in the majority of the agricultural areas of the region. As stated above, most of these areas have 2 well-defined seasons, rainy and dry. A large proportion of Latin American agricultural lands have rainy seasons which are 4 to 6 mo long. Any climatic changes which would lead to shorter rainy seasons could result in conditions similar to those existing in the Brazilian Northeast, drastically affecting crop productivity and transforming large and important crop production areas into marginal lands, with the consequent detrimental socioeconomic impact.

It is difficult to predict climate-change impacts in the vast livestock producing areas of the region. Production in these areas is based on the existence of relatively stable carbon, nitrogen, phosphorus and other nutrient balances in soil-plant-animal systems. An increase in temperature and/or a reduction in precipitation amount or variation in its distribution could result in unbalanced situations and unsustainable production systems (Baethgen et al. 1994).

\section{CONCLUSIONS}

The agricultural sector in Latin America has been subject to important variations in economic conditions and national policies. These conditions have drastically affected the structure of agricultural production, which has resulted in a large reduction of the proportion of small farmers, and significant migration to poor metropolitan areas. Even for larger, commercial farmers, unstable and often inconsistent agricultural policies have increased the vulnerability of the sector.

Additionally, large areas of Latin America are currently affected by interannual climatic variability related to the length of rainy seasons and the occurrence of extreme events (drought, floods, etc.). The few studies conducted in the region to specifically assess the impact of climate change on agriculture have revealed expected reductions and increased variability in crop productivity. Similar effects should be expected in the vast regions devoted to livestock production, since the systems are based on a fragile balance of nutrients, available water, stocking rates and pasture species.
The characteristics of the current situation of the agricultural sector in Latin America described in this article demonstrate its vulnerability to expected climate-change scenarios. Preparing Latin American agriculture to mitigate the potential negative effects of climate-change conditions will require strong and consistent efforts in both the scientific and policy sectors of the region.

\section{LITERATURE CITED}

Acock B, Allen LH Jr (1985) Crop responses to elevated carbon dioxide concentrations. In: Strain BR, Cure JD (eds) Direct effects of increasing carbon dioxide on vegetation. DOE/ER-0238, US Department of Energy, Washington, $\mathrm{DC}$

Baethgen WE (1994) Impacts of climate change on barley in Uruguay: yield changes and analysis of nitrogen management systems. In: Rosenzweig C, Iglesias A (eds) Implications of climate change for international agriculture: Crop modeling study. US EPA 230-B-94-003, Washington, DC

Baethgen WE, Magrin GO (1995) Assessing the impacts of climate change on winter crop production in Uruguay and Argentina using crop simulation models. In: Rosenzweig $C$ et al. (eds) Climate change and agriculture: analysis of potential international impacts. American Society of Agronomy Spec Publ 59, Madison, WI, p 207-228

Baethgen WE, Morón A, Díaz-Roselló RM (1994) Modeling long-term soil organic carbon changes in six cropping systems of SW Uruguay. International Soil Science Society Transcripts, Acapulco 9:300-302

CEPAL (Comisión Económica para América Latina y el Caribe) (1993) Statistical yearbook for Latin America and the Caribbean, 1993 edn. CEPAL, Montevideo

Cure JD (1985) Carbon dioxide doubling responses: a crop survey. In: Strain BR, Cure JD (eds) Direct effects of increasing carbon dioxide on vegetation. DOE/ER-0238, US Department of Energy, Washington, DC

FAO (Food and Agriculture Organization) (1992) The State of food and agriculture 1991. FAO, Rome

Hansen J, Fung I, Lacis A, Rind D, Lebedeff S, Ruedy R, Russell G, Stone P (1988) Global climate changes as forecast by Goddard Institute for Space Studies three-dimensional model. J Geophys Res 93:9341-9364

Hansen J, Russell G, Rind D, Stone P, Lacis A, Lebedeff S, Ruedy R, Travis L (1983) Efficient three-dimensional global models for climate studies: Models I and II. Mon Wea Rev III(4):609-662

IBSNAT (International Benchmark Sites Network for Agrotechnology Transfer Project) (1989) Decision Support System for Agrotechnology Transfer Version 2.1 (DSSAT V2.1). Dept of Agronomy and Soil Science, College of Tropical Agriculture and Human Resources, University of Hawaii, Honolulu

IPCC (Intergovernmental Panel on Climate Change) (1990) Climate change: the IPCC scientific assessment. Houghton JT, Jenkins GJ, Ephraums JJ (eds). Cambridge University Press, Cambridge

Liverman D, Dilley M, O'Brien K, Menchaca L (1994) Possible impacts of climate change on maize yields in Mexico. In: Rosenzweig C, Iglesias A (eds) Implications of climate change for international agriculture: crop modeling study. US EPA 230-B-94-003, Washington, DC

Manabe S, Wetherald R (1987) Large-scale changes of soil 
wetness induced by an increase in atmospheric carbon dioxide. J Atmos Sci 44:1601-1613

Parry ML, Carter TR, Konijn NT (1988) The impact of climatic variations on agriculture. Vol 1, Assessments in cool temperate and cold regions. Vol 2, Assessments in semi-arid regions. Kluwer, Dordecht

Rosenzweig C, Iglesias A (eds) (1994) Implications of climate change for international agriculture: crop modeling study. US EPA 230-B-94-003, Washington, DC

Sala OE, Paruelo JM (1994) Impacts of global climate change on maize production in Argentina. In: Rosenzweig C, Iglesias A (eds) Implications of climate change for international agriculture: crop modeling study. US EPA 230-B-94003, Washington, DC
Siqueira OJ, Farias JR, Sans LM (1994) Potential effects of global climate change for Brazilian agriculture: applied simulation studies for wheat, maize and soybeans. In: Rosenzweig C, Iglesias A (eds) Implications of climate change for international agriculture: crop modeling study. US EPA 230-B-94-003, Washington, DC

Wiggins S (1991) A Latin America review. In: Developing world agriculture. Grosvenor Press International, Oxford, p $34-43$

Wilson CA, Mitchell JFB (1987) A doubled $\mathrm{CO}_{2}$ climate sensitivity experiment with a global model including a simple ocean. J Geophys Res 92:13315-13343

World Bank (1986) World development report 1986. Oxford University Press, Oxford 